\title{
Nanocoating of microbial fuel cell electrodes for enhancing bioelectricity generation from wastewater
}

\author{
Yasser A. Attia ${ }^{1}\left(\right.$ Mohamed Samer $^{2}$ (1) $\cdot$ Mahmoud S. M. Mohamed $^{3} \cdot$ Elshaimaa Moustafa $^{2} \cdot$ Mohamed Salah $^{1}$. \\ Essam M. Abdelsalam ${ }^{1}$
}

Received: 27 October 2021 / Revised: 4 January 2022 / Accepted: 6 January 2022

(c) The Author(s) 2022

\begin{abstract}
Microbial fuel cells (MFCs) are devices where bacteria generate electrical energy by oxidizing organic matter in wastewater. The implementation of MFCs on a commercial scale is limited due to electrode resistances, which are one of the key factors limiting electricity generation. This study presents a method to maximize the electrical power production from MFCs by coating the electrodes using nanomaterials which leads to prototyping novel electrodes having higher electrical conductivity than common electrodes. The voltage reached $1.234 \mathrm{~V}$ directly after operating the MFCs, with nanocoated electrodes, and showed voltage stability till the end of the $140 \mathrm{~h}$ interval with a peak value of $1.367 \mathrm{~V}$ with a maximum areal power density of $116 \mathrm{~mW} \mathrm{~m}^{-2}$ and a maximum volumetric power density of $15.6 \mathrm{~mW} \mathrm{~m}^{-3}$. However, the voltage of the control (without coating) was steadily increased to $0.616 \mathrm{~V}$ after $22 \mathrm{~h}$ with a maximum areal power density of $23.6 \mathrm{~mW} \mathrm{~m}^{-2}$ and a maximum volumetric power density of $3.2 \mathrm{~mW} \mathrm{~m}^{-3}$ then showed voltage stability till the end of the $140 \mathrm{~h}$ interval. It was found that the coulombic efficiency of the MFCs where its electrodes are coated with graphitic carbon nitride nanosheets was higher than graphene, carbon nanotubes, and the control in a descending order, respectively. By this method, it is possible to improve the electrical conductivity of the MFCs which results in increasing the generated electrical power by 4.9 times the conventional method.
\end{abstract}

Keywords Microbial fuel cells $\cdot$ Nanotechnology $\cdot$ Nanomaterials $\cdot$ Electricity generation $\cdot$ Wastewater treatment

\section{Introduction}

Microbial fuel cells are devices that produce electricity by microbes oxidizing simple chemicals like glucose and complex organic materials in the wastewater [1]. Bacteria grow on the anode, oxidizing organic matter and releasing electrons. The cathode is sparked with air to provide dissolved oxygen for the cathode's reaction of electrons, protons, and oxygen, completing the circuit and generating

Yasser A. Attia

yasserniles@niles.edu.eg

$\triangle$ Mohamed Samer

msamer@agr.cu.edu.eg

1 National Institute of Laser Enhanced Sciences (NILES), Cairo University, Giza 12613, Egypt

2 Department of Agricultural Engineering, Faculty of Agriculture, Cairo University, Giza 12613, Egypt

3 Department of Botany and Microbiology, Faculty of Science, Cairo University, Giza 12613, Egypt electricity. Microbial fuel cells convert a biodegradable substrate directly into electricity and are new types of bioreactors which use exoelectrogenic biofilms for electrochemical energy production [2-4].

Microbial fuel cells have advantages over other technologies used for generating energy from organic matter. First, the direct conversion of substrate into electricity permits high conversion efficiencies. Second, they operate efficiently at ambient temperature. Third, they do not require the treatment of gases generated in the cell. Fourth, they do not require additional energy to aerate the cathode, given that it can be aerated passively. Finally, they have the potential for application in remote areas without electrical infrastructure, making them an additional renewable energy option to meet global energy requirements [2,3,5]. There is a variety of types and configurations of microbial fuel cells (MFCs), where the most common ones are single chamber microbial fuel cells, double chamber microbial fuel cells and stacked microbial fuel cells [1-3, 5-7]. 
More than 30 pure isolates have been reported in microbial fuel cell research, and the mainstream exoelectrogens include Geobacter, Shewanella, and Pseudomonas [8]. Consequently, most of the research operated the microbial fuel cells within a temperature range from 25 to $30^{\circ} \mathrm{C}$. Another important factor is the $\mathrm{pH}$, where the highest power densities occur at $\mathrm{pH}$ values near neutral. Precisely, during the experiments the $\mathrm{pH}$ should be maintained at 6.7 [2]. Furthermore, the hydraulic retention time (HRT) ranges from 14 to 20 days in most studies [1, 9-12]. However, in practice, microbial fuel cells can be operated continuously up to 150 days [13].

On the other hand, the nanomaterials can be synthesized in the form of nanocubes, nanowires, nanorods, nanotubes, and nanoparticles (nanospheres and nanocapsules). The main features of implementing nanotechnology are that the physical, chemical, electrical, thermal, and further engineering properties of the synthesized nanomaterials differ intrinsically from the original material properties [14-17].

Electrode's conductivity is a critical factor affecting the microbial fuel cell performance, where prototyping electrodes having high electrical conductivity and low resistance to electric current is a key issue in the scientific research and development endeavors in this field [18]. Cathode resistance is evaluated to be the major factors limiting electricity generation by MFCs [7]. Anode biofilm is a critical component for electrogenesis in microbial fuel cells. Better understanding of the biofilm development process on the electrode surface is believed to enhance microbial fuel cell performance [12]. Besides, Rabaey and Verstraete [19] mentioned that the potential losses during electron transfer in MFCs are loss owing to bacterial electron transfer, losses at the anode, losses at the MFCs resistance - useful potential difference - and membrane resistance losses, losses at the cathode, and losses owing to electron acceptor reduction.

Using nanomaterials with different sizes and shapes for covering the electrodes (anode and cathode) will lead to prototyping novel electrodes having higher electrical conductivity than common electrodes. As a result, the microbial fuel cell's efficiency improves. Graphene, carbon nanotubes, and graphitic carbon nitride have comprehensive performance on opteoelectronics, according to its tremendous physicochemical, mechanical properties, also its high electrical and thermal conductivities are used in many electronic applications [20-22]. Furthermore, it is hypothesized that the nanomaterials will improve the biofilm development process on the electrode surface. The objective of this study is to prototype novel electrodes (anode and cathode) with higher electrical conductivity and lower electrical resistance which ultimately improves the efficiency of microbial fuel cells.

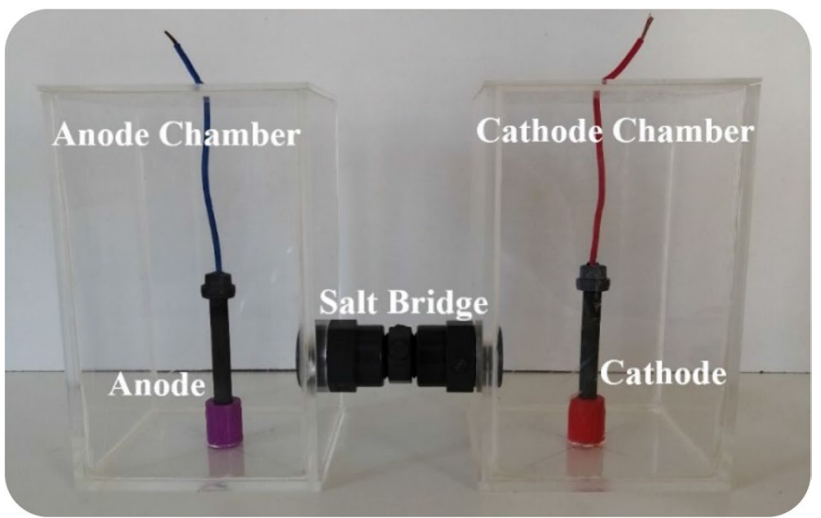

Fig. 1 A photograph of one of the manufactured microbial fuel cells

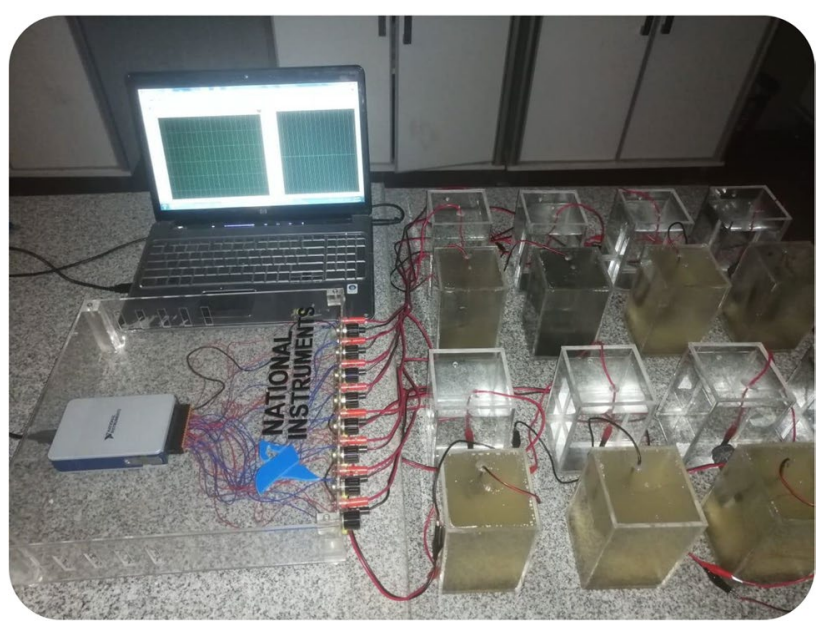

Fig. 2 A photograph showing the installed MFCs in operation

\section{Materials and methods}

\subsection{Manufacturing and installing the MFCs}

Microbial fuel cells (Fig. 1) were locally manufactured and made of poly(methyl methacrylate), also known as acrylic or plexiglass. Each microbial fuel cell has an elevation of $15 \mathrm{~cm}$ and $10 \times 10 \mathrm{~cm}$ for the section, where the anode chamber was filled with a substrate volume of $1.5 \mathrm{~L}$, and the cathode chamber was filled with a water volume of 1.5 L. Furthermore, Fig. 2 shows the manufactured microbial fuel cells in operation during the experiments, where the electrodes were coated with nanomaterials. 


\subsection{Isolation and monitoring of the electrogenic bacterial growth in MFCs}

In order to examine the electrogenic bacterial growth in MFCs over time before and after electricity generation, $10 \mathrm{~mL}$ from anode chamber was diluted in $90-\mathrm{mL}$ sterile saline. The bacterial count was initiated by making tenfold dilutions of these suspensions in a sterile saline solution up to $10^{-5}$. Then the serially diluted suspensions $(50 \mu \mathrm{L})$ was spread onto Luria Bertani (LB) agar medium and incubated for $24 \mathrm{~h}$ at $37^{\circ} \mathrm{C}$. The colony forming unit (CFU) was calculated by dividing (the total number of bacteria colonies $\times$ dilution factor) by (the volume of sample added to the agar plate).

The results indicate that at the two MFC conditions (coated anode with CNT and non-coated anode) exponential

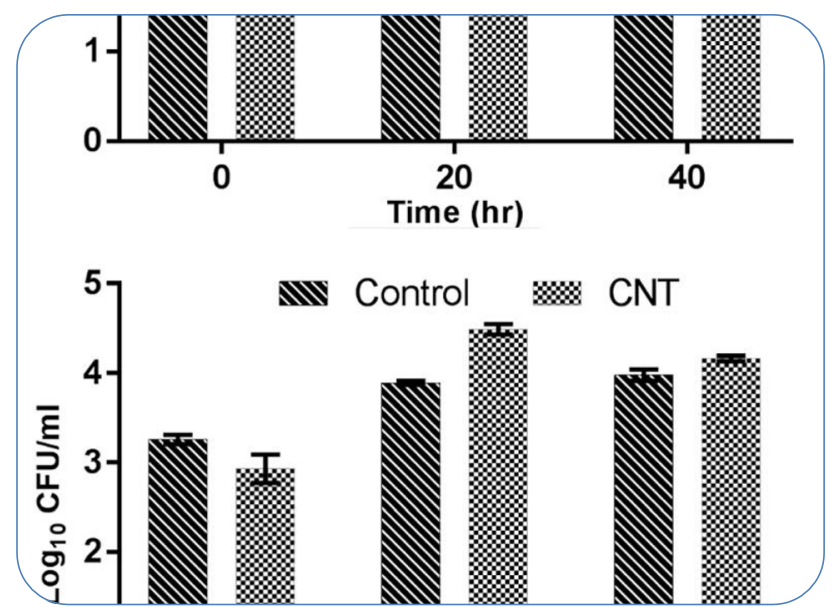

Fig. 3 Growth of bacteria over time in MFCs as measured by viable cell count. Control; graphite electrodes, CNT; anode coated with 50-mg carbon nanotubes. Aliquots removed at different time points were diluted tenfold with saline solution prior to counting increase in the electrogenic bacterial growth after $20 \mathrm{~h}$ of operation. However, a slight decrease in bacterial growth after $40 \mathrm{~h}$ of operation as the nutrient in the MFCs start to decrease. Interestingly, higher bacterial growth was recorded in the MFCs when the electrodes were coated with 50-mg carbon nanotube compared to control (Fig. 3). It was observed that the isolated electrogenic bacteria have the same morphological appearances, Gram negative and fermentative bacteria (Fig. 4).

\subsection{Nanomaterial preparation}

\subsubsection{Preparation of carbon nanotubes}

Carbon nanotubes (CNTs) were fabricated by using template and catalyst-free CVD synthesis inside nanoporous anodic alumina membranes (NAAMs). A CVD system with a twostage furnace, a cylindrical-quartz tube with dimensions of 43 and $1000 \mathrm{~mm}$ in diameter and length, and temperature and gas flow controllers were used to carry out the fabrication process $[23,24]$.

\subsubsection{Preparation of graphene}

A modified Hummer's method was used to prepare graphene oxide (GO) [25-32]. A typical procedure involved adding $\mathrm{H}_{2} \mathrm{SO}_{4}(150 \mathrm{~mL})$ to a flask containing graphite $(6 \mathrm{~g})$ in an ice bath while stirring. After that, $18 \mathrm{~g}$ potassium permanganate $\left(\mathrm{KMnO}_{4}\right)$ was slowly added to the above mixture, and the ice bath was removed after several minutes. The color of the solution turned to dark green under continued stirring for $2 \mathrm{~h}$ at $35{ }^{\circ} \mathrm{C}$. After that, $300 \mathrm{~mL}$ of water was slowly added to the reaction mixture, and the conical flask was immersed in boiling water for $30 \mathrm{~min}$. After that, the flask was cooled in an ice bath, and $1 \mathrm{~L}$ distilled water was added to stop the reaction. Twenty milliliters $\mathrm{H}_{2} \mathrm{O}_{2}(30 \%)$
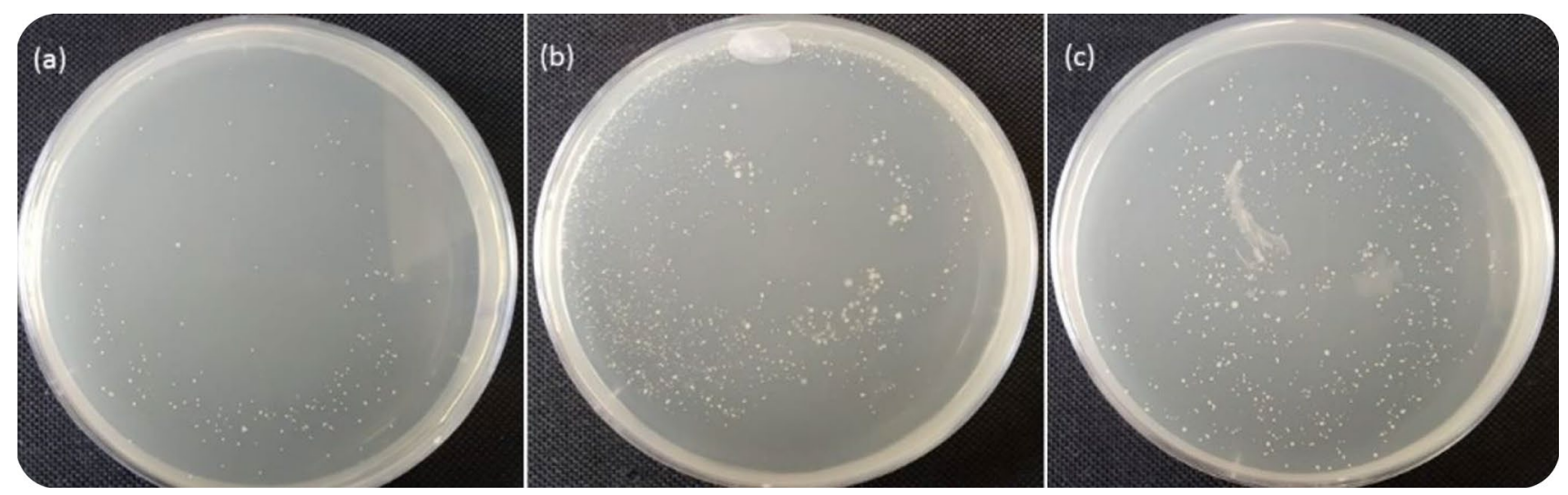

Fig. 4 The total bacterial count of MFCs over time using LB agar medium. Aliquots from anode chamber were collected after 0 (a), 20 (b), and 40 (c) $\mathrm{h}$ of operation and diluted up to $10^{-5}$ 
was added to reduce the residual permanganate to soluble manganese ions. Eventually, the precipitation was centrifuged and washed with 1-M HCl and distilled water several times, and then vacuum dried at $60^{\circ} \mathrm{C}$ for $24 \mathrm{~h}$. After $4 \mathrm{~h}$ of heating the filtrate at $60^{\circ} \mathrm{C}$, the dry GO powder is obtained. To obtain rGO from GO, place $100 \mathrm{mg}$ of dried GO powder in an empty beaker. The beaker was covered with aluminum foil with many punched pores and placed in a hood on a hot plate set at $350{ }^{\circ} \mathrm{C}$ for $10 \mathrm{~min}$. The rGO powder that resulted was then recovered from the beaker [26].

\subsubsection{Preparation of graphitic carbon nitride nanosheets}

Graphitic carbon nitride $\left(\mathrm{g}-\mathrm{C}_{3} \mathrm{~N}_{4}\right)$ nanosheets were synthesized by heating $50 \mathrm{~g}$ of urea at $500{ }^{\circ} \mathrm{C}$ in air for $3 \mathrm{~h}[33,34]$.

\subsection{Nanocoating of the electrodes}

To prepare a modified carbon electrode with the electrocatalyst powder, the carbon surface $\left[\right.$ area $=0.5 \mathrm{~cm}^{2}$ ] was first polished with soft emery papers and rinsed with double distilled water and ethanol. Twenty milligrams of the electrocatalyst powder was dispersed in a mixture of 1-mL isopropyl alcohol, $1-\mathrm{mL}$ double distilled water and $1 \mathrm{~mL}$ of $0.5 \mathrm{wt} \%$ Nafion solution with ultrasonic agitation for $20 \mathrm{~min}$ to fabricate the electrocatalyst ink. Fifty microliters of this electrocatalyst dispersion was deposited on carbon electrode surface and kept to dry in a desiccator overnight [35].

\subsection{Characterization}

UV-Vis spectra were obtained with Agilent Cary 60 UV/Vis Instrument Bundle using 1-cm path length Hellma quartz cuvettes. The crystal structures of the samples were analyzed by powder X-ray diffraction (XRD, LabX XRD-6000, $\mathrm{Cu} \mathrm{Ka}, \lambda=1.5406 \AA$, Shimadzu, Japan). Scanning electron microscopy (SEM) images were obtained with a ZEISS FESEM ULTRA Plus (equipped with EDX analyzer) microscope with a Philips CM20 microscope, operating at an accelerating voltage of $200 \mathrm{kV}$. Several drops from the sample dispersion were deposited onto an aluminum pin stubs and left to evaporate at room temperature. The FTIR spectra were recorded on a "SHIMADZU FTIR 8000" spectrometer model on $\mathrm{KBr}$ pellet samples between 4000 and $400 \mathrm{~cm}^{-1}$.

\subsection{Waste handling}

Sample of wastewater and sludge was collected from Zenein Wastewater Treatment Plant (Zenein, Bulaq Dakrur, Giza Governorate). This sample was used to fill in the microbial fuel cells and to start the experiments. The properties of wastewater sample were documented as follows: the values of total solids (TS), volatile solids (VS), ash, $\mathrm{pH}$, and organic carbon (OC) of wastewater, sludge, and their mixture are listed in Table 1.

\subsection{Conducting the measurements}

A National Instruments voltage and current input C Series module (NI 9207 Spring, 16-Ch) was used for voltage and current measurements of all MFCs at the same time which is important for constant conditions of the measurements. The NI-9207 is a combination voltage and current input module designed with industrial systems in mind. It features 8 current and 8 voltage inputs, 500 sample/second, $\pm 20 \mathrm{~mA}$ current inputs, $\pm 10 \mathrm{~V}$ voltage inputs, 24-bit high-resolution mode, with built-in $50 / 60-\mathrm{Hz}$ noise rejection.

\subsection{Calculations}

\subsubsection{Coulombic efficiency}

The coulombic efficiency of the microbial fuel cell, which is defined as the quantity of organic matter recovered as electricity, was calculated according to the following equations $[2,36]$ :

$\mathrm{CE}=\frac{\mathrm{Cp}}{\mathrm{Cti}} \times 100 \%$

where

$C_{p} \quad$ total coulombs $(C)$ is calculated as the integral of current $(A)$ with respect to time $(h)$

$C_{t i}$ theoretical amount of coulombs $(C)$

The graph of current (Y-axis) against microbial fuel cell operation time (X-axis) was used to determine $C_{p}$. The total charge $(q)$ in coulombs is obtained by integrating the area under the curve (from $t=0$ to $140 \mathrm{~h}$ ). On the other hand, the theoretical amount of coulombs $\left(C_{t i}\right)$ was calculated as follows:

Table 1 Total solids (TS), volatile solids (VS), ash, pH, and organic carbon (OC) of wastewater, sludge, and mixture

\begin{tabular}{llll}
\hline Item & Wastewater & Sludge & Mixture \\
\hline Total solids TS\% & $0.47 \pm 0.16$ & $3.91 \pm 0.79$ & $1.73 \pm 0.04$ \\
Volatile solids VS\% & $0.42 \pm 0.15$ & $2.4 \pm 0.43$ & $1.01 \pm 0.03$ \\
VS (\% as TS) & $88.53 \pm 0.38$ & $61.49 \pm 1.44$ & $58.13 \pm 3.15$ \\
Ash & $0.05 \pm 0.02$ & $1.51 \pm 0.36$ & $0.73 \pm 0.07$ \\
Organic carbon $(\%)$ & $51.35 \pm 0.22$ & $35.67 \pm 0.84$ & $33.72 \pm 1.83$ \\
pH & 6.60 & 6.90 & 6.20 \\
\hline
\end{tabular}


$\mathrm{C}_{\mathrm{ti}}=\left[\frac{\mathrm{F} \times \mathrm{b} \times \mathrm{S} \times \mathrm{v}}{\mathrm{M}}\right]$

where

$F \quad$ Faraday's constant $\left(96,485.33 \mathrm{C} \mathrm{mol}^{-1}\right.$ of electrons)

$b$ number of moles of electrons produced per mole of substrate ( $b=4$ for wastewater)

$S$ substrate concentration $\left(\mathrm{g} \mathrm{L}^{-1}\right)$, where $S=1000-999.352=0.648 \mathrm{~g} \mathrm{~L}^{-1}$ for wastewater

$v$ substrate volume (L), which was $1.5 \mathrm{~L}$ in the anode chamber

$M$ molecular weight of the substrate $(M=32$ for wastewater)

\subsubsection{Resistance}

According to Ohm's Law equation, the resistance was calculated as follows:

$\mathrm{V}=\mathrm{I} \times \mathrm{R}$

where

$V$ voltage, $V$

$I$ current, $A$

$R$ external resistance, $\Omega$

\subsubsection{Power and power density}

According to the Power Law equation, the power was calculated as follows:

$\mathrm{P}=\mathrm{I} \times \mathrm{V}$

where

$P \quad$ power, $W$
The power density $\left(P_{D}\right)$ generated by the microbial fuel cell was calculated in $\mathrm{W} \mathrm{m}^{-3}$ based on the substrate volume $(v)$ and the power calculated using Eq. (4), as follows:

$P_{D}=\frac{I \times V}{V}$

The areal power density was calculated as follows [37]:

$\mathrm{P}_{\mathrm{AD}}=\frac{\mathrm{I} \times \mathrm{V}}{\mathrm{A}}$

where

$A$ the projected surface area of the anode, $\mathrm{m}^{-2}$.

$P_{A D}$ areal power density, $\mathrm{W} \mathrm{m}^{-2}$.

\section{Results}

\subsection{Characteristics of the nanomaterials}

Carbon nanotubes (CNTs) with diameters of $40-50 \mathrm{~nm}$ and lengths of about $20 \mathrm{~mm}$ are shown in Fig. 5a. The pristine $\mathrm{g}_{-} \mathrm{C}_{3} \mathrm{~N}_{4}$, as typical layered and stacked structures are observed in the sample as shown in the SEM image given in Fig. 5b which is composed of nanosheet sheet-like structures and fluffier. The rGO nanosheets, however, are layer organized, irregular, and folding, as demonstrated in the SEM image of Fig. 5c. They are entangled with each other. Figure $5 \mathrm{c}$ shows that the single- or few-layer rGO nanosheets are with lots of wrinkles.

In Fig. 6, it is shown that the XRD pattern of CNTs contained characteristic diffraction peaks at t $26.52^{\circ}, 42.48^{\circ}$, $54.71^{\circ}$, and $78.43^{\circ} 2 \theta$, owing to (220), (100), (004), and (110) reflection of planes, respectively [23, 24]. The XRD pattern of pure-g- $\mathrm{C}_{3} \mathrm{~N}_{4}$ revealed that peaks at $26.73^{\circ}$ and $13.37^{\circ}$ can be assigned to (002) inter-layer structural
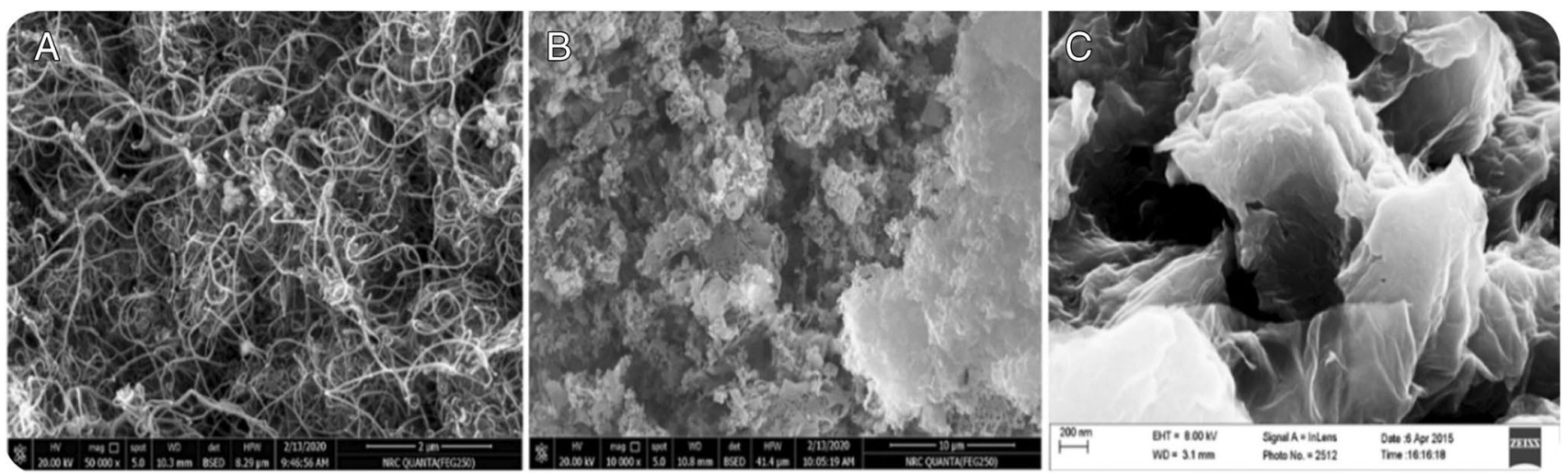

Fig. 5 SEM images of the prepared carbon nanotubes (a), g- $\mathrm{C}_{3} \mathrm{~N}_{4}(\mathbf{b})$, and $\mathrm{rGO}(\mathbf{c})$, respectively 


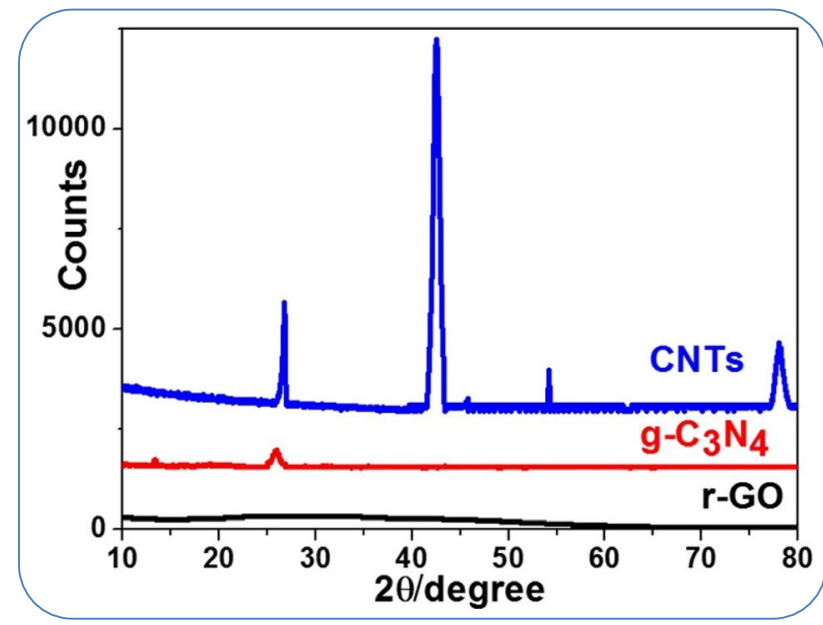

Fig. 6 XRD patterns of the prepared carbon nanotubes, $\mathrm{g}-\mathrm{C}_{3} \mathrm{~N}_{4}$, and $\mathrm{rGO}$, respectively

packing crystal plane and (100) inter-planar stacking diffraction planes, respectively. The prominent peak at $26.73^{\circ}$ confirms the stacking reflection of conjugated aromatic systems, revealing a graphitic structure with an interlayer spacing $0.326 \mathrm{~nm}[33,38]$. The $3 \mathrm{D}$ character of graphene oxide is reduced as indicated by the disappearance of the narrow $\mathrm{XRD}$ reflection at $2 \theta=10.8 \mathrm{~A}^{\circ}$. In contrast to the XRD pattern of the GO powder sample, the XRD pattern of the r-GO yielded only a new peak at $24.1^{\circ}$ corresponding to (002), probably due to intra layer spacing [39], as shown in Fig. 6.

The FTIR spectrum of raw CNTs in Fig. 7 exhibits a broad absorption peak in the range of $3450-3460 \mathrm{~cm}^{-1}$ correspond to $-\mathrm{OH}$ group, indicating of existence of the hydroxyl groups on the surface of the CNTs. Indeed, it is found that these groups can be attributed to the oxidation

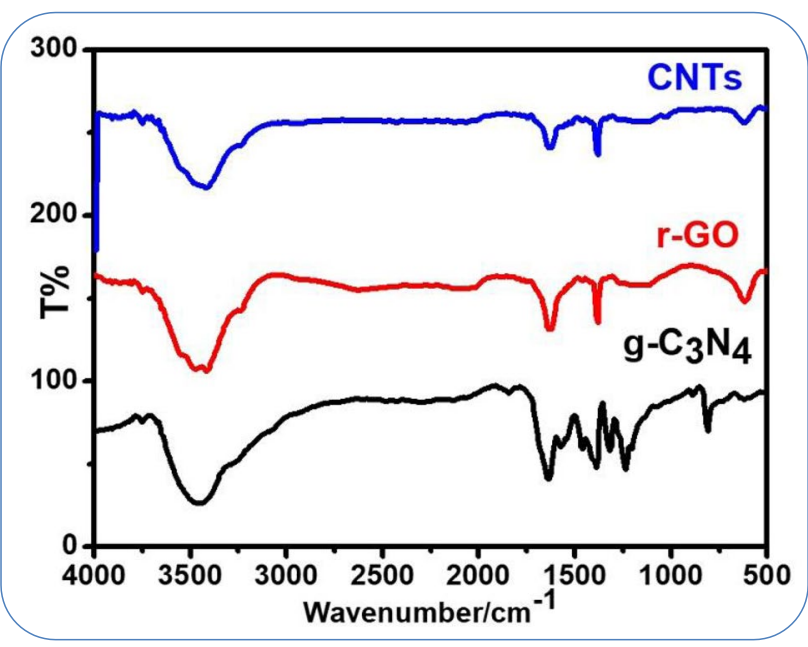

Fig. 7 FTIR of the prepared carbon nanotubes, g- $\mathrm{C}_{3} \mathrm{~N}_{4}$, and $\mathrm{rGO}$, respectively of the carbon surface after exposure to air atmosphere and the absence of catalysts during the synthesis process (i.e., less crystalline structure). The $\mathrm{C}-\mathrm{H}$ stretch vibration is represented by the two peaks at 2950 and $2850 \mathrm{~cm}^{-1}$. The $\mathrm{C}-\mathrm{C}$ characteristic peak can be observed at $1580 \mathrm{~cm}^{-1}$. Another peak at $1650 \mathrm{~cm}^{-1}$ is the $\mathrm{C}-\mathrm{O}$ stretching mode of the functional groups on the surface of the MWCNTs or arising from the absorption of atmospheric $\mathrm{CO}_{2}$ on the surface of the composites. The $\mathrm{C}-\mathrm{O}$ stretching mode is responsible for the peak at $950 \mathrm{~cm}^{-1}$.

The FTIR spectrum of $\mathrm{g}-\mathrm{C}_{3} \mathrm{~N}_{4}$, the peaks at 1145,1213 , 1393,1587 , and $1648 \mathrm{~cm}^{-1}$ which are attributed to the stretching modes of $\mathrm{CN}$ heterocycles associated with skeletal stretching vibrations of aromatic rings, while the peak at $810 \mathrm{~cm}^{-1}$ corresponds to breathing mode of the triazine units of $\mathrm{g}_{-} \mathrm{C}_{3} \mathrm{~N}_{4}$ (Fig. 7). The three bands at $1724 \mathrm{~cm}^{-1}$, $1222 \mathrm{~cm}^{-1}$, and $1050 \mathrm{~cm}^{-1}$ assigned to carbonyl, epoxy, and alkoxide functional groups, respectively, are dramatically reduced in graphene compared to GO, indicating that the sheets have been deoxygenated [27-31], as seen in Fig. 7.

\subsection{Effects of nanocoating on MFCs}

The graphitic carbon nitride $\left(\mathrm{g}-\mathrm{C}_{3} \mathrm{~N}_{4}\right)$ nanosheets deliver the highest performance among all other nanomaterials. The results of the experiments show that coating the electrodes of microbial fuels cells by graphitic carbon nitride $\left(\mathrm{g}-\mathrm{C}_{3} \mathrm{~N}_{4}\right)$ nanosheets increases the generated electrical power by 4.9 times the control which is without coating (Fig. 8). Another issue, using a pump to intrude air (oxygen) into the cathode chamber has a strong effect on the amount of generated power from the microbial fuel cells (Figs. 9 and 10). In case a pump is used to intrude air into the cathode chamber, the results show that the voltage value reaches $1.234 \mathrm{~V}$ directly after operating the MFCs with a constant loading resistance of $80 \mathrm{k} \Omega$, where the electrodes are coated with graphitic carbon nitride $\left(\mathrm{g}-\mathrm{C}_{3} \mathrm{~N}_{4}\right)$ nanosheets, and shows voltage stability till the end of the $140 \mathrm{~h}$ interval with a constant loading resistance of $80 \mathrm{k} \Omega$, where the peak voltage reaches a value of $1.367 \mathrm{~V}$ (Fig. 8) with a maximum areal power density of $116 \mathrm{~mW} \mathrm{~m}^{-2}$ and a maximum volumetric power density of $15.6 \mathrm{~mW} \mathrm{~m}^{-3}$. However, the voltage of the control (without coating) is steadily increased to $0.616 \mathrm{~V}$ after $22 \mathrm{~h}$ with a maximum areal power density of $23.6 \mathrm{~mW} \mathrm{~m}^{-2}$ and a maximum volumetric power density of $3.2 \mathrm{~mW} \mathrm{~m}^{-3}$, with a constant loading resistance of $80 \mathrm{k} \Omega$, then shows voltage stability till the end of the $140 \mathrm{~h}$ interval. In case no pump is used to intrude air into the cathode chamber; however, the voltage reaches its peak value after $55 \mathrm{~h}$ of operating the microbial fuel cells (Fig. 9). In both cases, the peak value is preserved till the end of the experiment which lasts $140 \mathrm{~h}$. By this method, it is possible to improve the electrical conductivity of the MFCs which results in increasing 


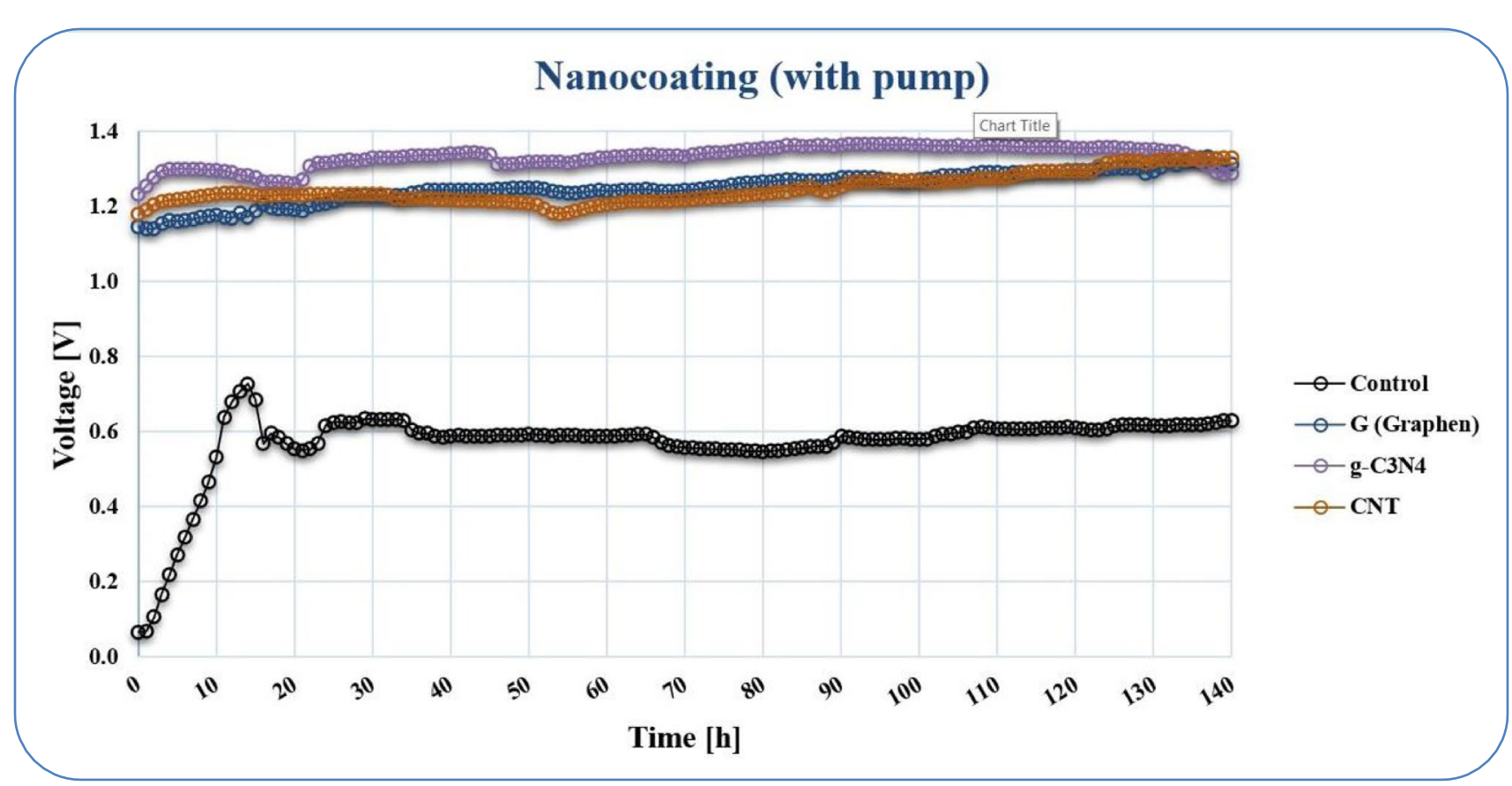

Fig. 8 The voltage of the microbial fuel cells where a pump was used to intrude air into the cathode chamber

the generated electrical power by 4.9 times the conventional method. Table 2 shows these data for all treatments.
The electric current of the microbial fuel cells where a pump is used to intrude air into the cathode chamber

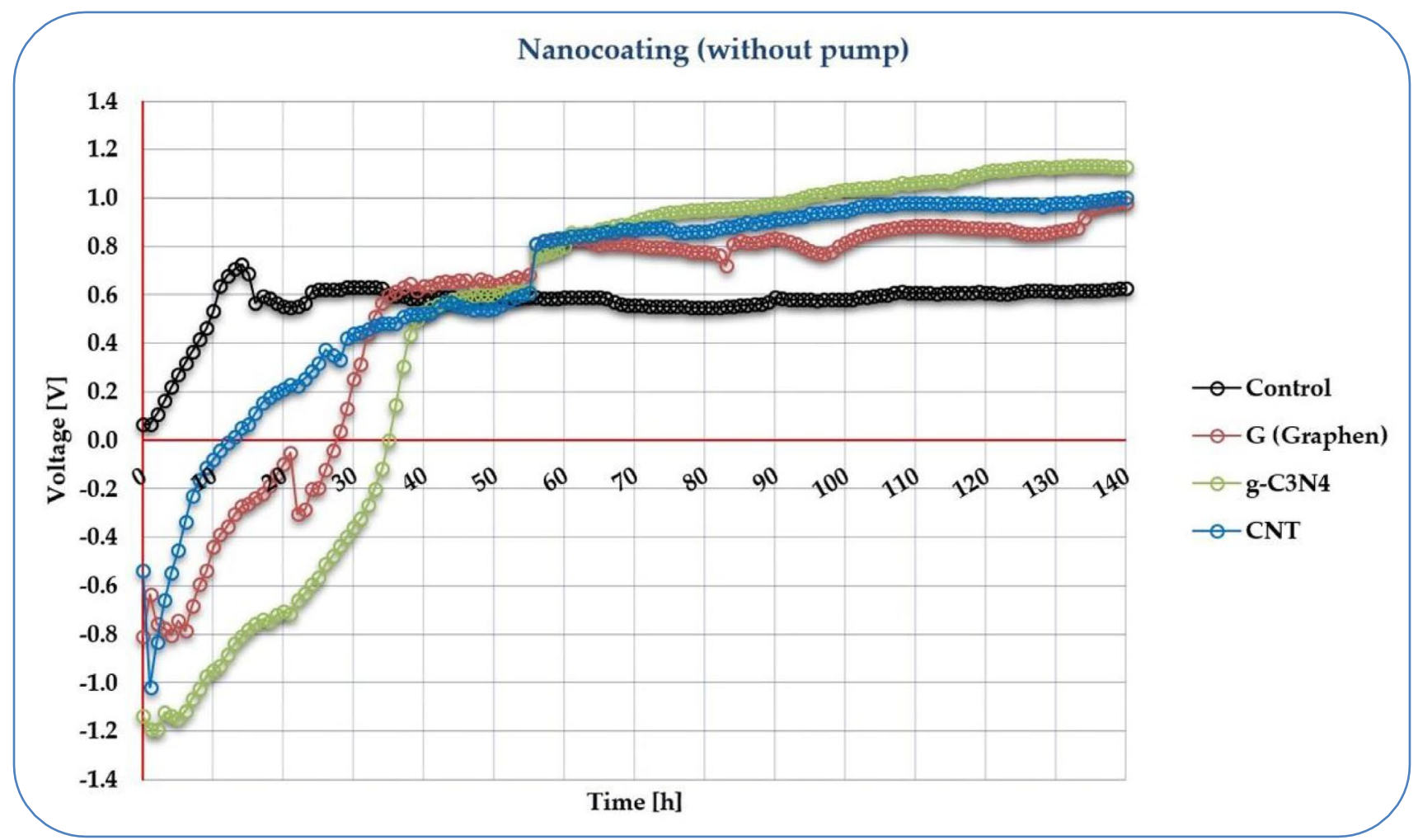

Fig. 9 The voltage of the microbial fuel cells where no pump was used to intrude air into the cathode chamber 


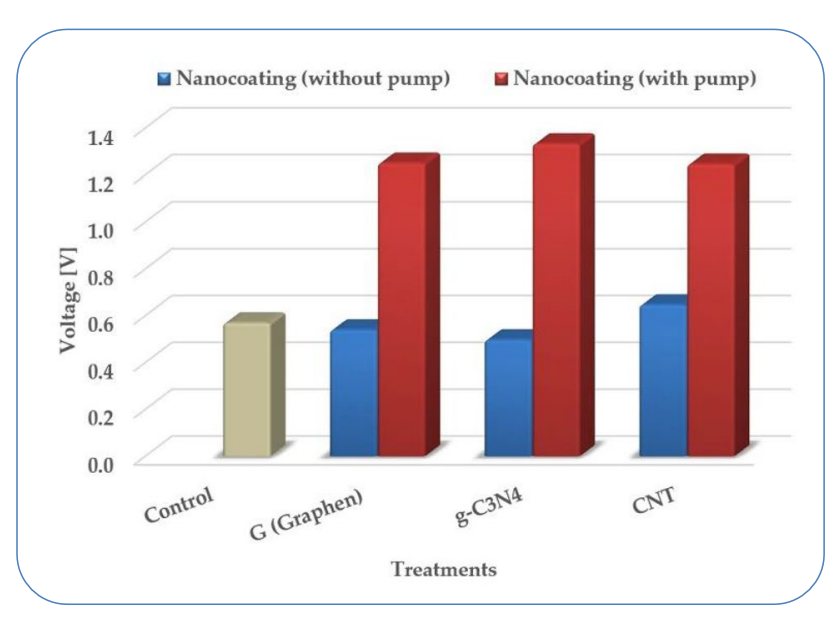

Fig. 10 The voltage of the microbial fuel cells in the case where no pump was used to intrude air into the cathode chamber in comparison to the case where a pump was used to intrude air into the cathode chamber

is plotted for all treatments (Fig. 11). For each curve, the total coulombs are calculated as the integral of current with respect to time and then divided by the theoretical amount of coulombs to get the coulombic efficiency of the microbial fuel cell. The results show that the coulombic efficiency of the microbial fuel cell where its electrodes are coated with graphitic carbon nitride $\left(\mathrm{g}-\mathrm{C}_{3} \mathrm{~N}_{4}\right)$ nanosheets, graphene, and carbon nanotubes (CNTs) compared to the control are $19.91 \%, 18.68 \%, 18.62 \%$, and $8.54 \%$, respectively.

The electrode's durability is a critical parameter that determines MFC performance. The cell voltage was measured using a constant external resistance of $80 \Omega$ to determine the durability performance. In all of the treatments, the voltage of the cell steadily increased. The voltage values increased, which could be related to the consistent and healthy growth of bacterial colonization on the anode surface. The treatments demonstrated high voltage in the second cycle, with $>95 \%$ efficiency compared to the first cycle. The voltage efficiency of the microbial fuel cell where its electrodes are coated with graphitic carbon nitride $\left(g-\mathrm{C}_{3} \mathrm{~N}_{4}\right)$ nanosheets, graphene, and carbon nanotubes (CNTs) is $96.2 \%, 95.7 \%$, and $92.4 \%$, respectively, compared to the first cycle.

\section{Discussion}

The present investigation focused on using microbial fuel cells for generating electrical power from wastewater. This wastewater is annually produced in large quantities thereafter subjected to physical, biological, and chemical treatment processes in wastewater treatment plants. Therefore, this approach would not only remediate wastewater, but also generate electricity. However, microbial fuel cells use in wastewater treatment plants is restricted due to resistances of the electrodes which are the major factors limiting electricity generation. This study focused on using nanomaterials for coating the electrodes of microbial fuel cells for increasing electrical power generation from wastewater which leads to prototyping novel electrodes having higher electrical conductivity than common electrodes. Consequently, the efficiency of the microbial fuel cell increases. It was found that, the coulombic efficiency of the microbial fuel cell where its electrodes are coated with graphitic carbon nitride nanosheets was higher than graphene, carbon nanotubes, and the control in a descending order, respectively. This also indicated that prepared electrodes were very compatible for bacteria growth and non-hazard for living microorganisms. Due to their unique properties, electrodes coated with $\mathrm{g}-\mathrm{C}_{3} \mathrm{~N}_{4}$ showed high performance. Graphitic carbon nitride $\left(\mathrm{g}_{-} \mathrm{C}_{3} \mathrm{~N}_{4}\right)$ is a twodimensional conjugated polymer with outstanding analytical merits such as non-toxicity, metal-free, high stability, lowcost synthesis, catalytic ability, low band gap energy, unique electronic properties, and electron-rich properties.

In accordance with the current work, previous studies have demonstrated the use of coating materials is a promising technique for extending the electrical power generation from wastewater using microbial fuel cells $[11,40]$. Cui et al. electropolymerized the polyaniline on the surface of macroporous graphite felt microbial fuel cell anode then deposited carbon nanotubes, where the output voltage attains a value of $342 \mathrm{mV}$. In the present study, however, coating the electrodes with nanomaterials delivered an output voltage of $1370 \mathrm{mV}$ [41]. This can be attributed to the types of used nanomaterials, especially the $\mathrm{g}-\mathrm{C}_{3} \mathrm{~N}_{4}$ nanosheets and the coating method. On the other hand, Erbay et al. controlled the geometrical properties of carbon nanotube electrodes, where the output voltage attained $500 \mathrm{mV}$ [42]. Therefore, it can be said that the invention trend of coating the electrodes

Table 2 The highest voltage, electric current, power, aerial power density, and volumetric power density of all treatments

\begin{tabular}{lllllllll}
\hline Nanocoating & $V(\mathrm{~V})$ & $I(\mathrm{~A})$ & $R(\mathrm{k} \Omega)$ & $P(\mathrm{~W})$ & $v\left(\mathrm{~m}^{3}\right)$ & $P_{D}\left(\mathrm{~mW} / \mathrm{m}^{3}\right)$ & $A\left(\mathrm{~m}^{2}\right)$ & $P_{A D}\left(\mathrm{~mW} / \mathrm{m}^{2}\right)$ \\
\hline g-C $\mathrm{N}_{4}$ & 1.367 & $1.708 \mathrm{E}-05$ & 80 & $2.33586 \mathrm{E}-05$ & $1.50 \mathrm{E}-03$ & 15.6 & $2.01 \mathrm{E}-04$ & 116.2 \\
Graphene & 1.333 & $1.666 \mathrm{E}-05$ & 80 & $2.22111 \mathrm{E}-05$ & $1.50 \mathrm{E}-03$ & 14.8 & $2.01 \mathrm{E}-04$ & 111 \\
CNTs & 1.330 & $1.660 \mathrm{E}-05$ & 80 & $2.21113 \mathrm{E}-05$ & $1.50 \mathrm{E}-03$ & 14.7 & $2.01 \mathrm{E}-04$ & 110 \\
Control & 0.616 & $0.770 \mathrm{E}-05$ & 80 & $0.47432 \mathrm{E}-05$ & $1.50 \mathrm{E}-03$ & 3.2 & $2.01 \mathrm{E}-04$ & 23.6 \\
\hline
\end{tabular}




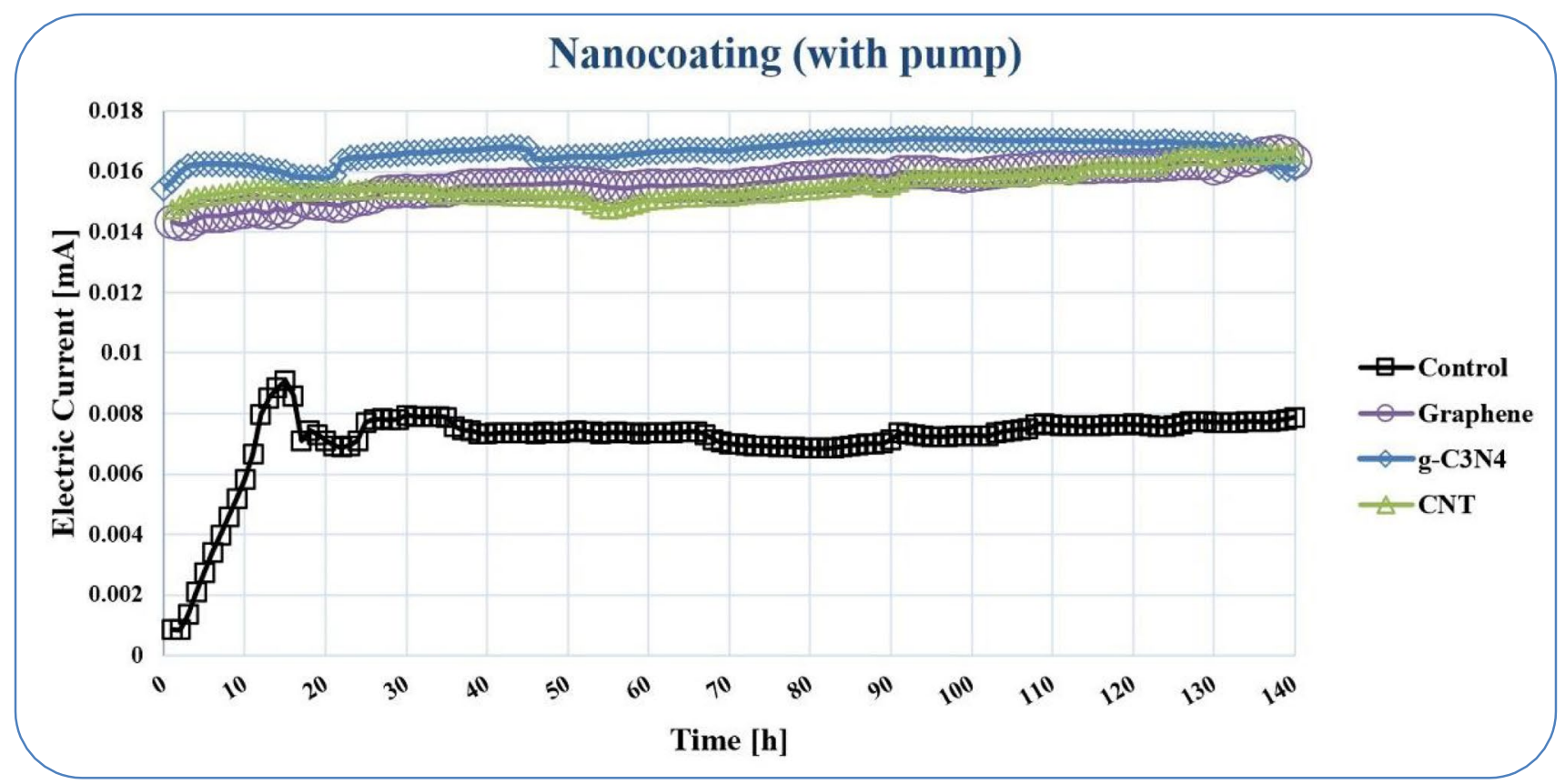

Fig. 11 The electric current of the microbial fuel cells where a pump was used to intrude air into the cathode chamber

agree with the present study, but with different results due to the fact that different types of nanomaterials and coating methods were applied which ultimately delivered different output voltages. Further studies have investigated materials - other than nanomaterials - for coating the electrodes, such as: manganese dioxide [11], a defined pore size (DPC) material made of silica and sucrose [40], and macro-fiber composites [9].

In this study, it was found that nanomaterials can accelerate electron transfer and oxygen reduction in the microbial fuel cells which agrees with Kamali et al. [43]. Besides, in the current research, carbon-based electrodes have enhanced and increased the electroactive surface area, increased the electrical conductivity, and promoted biofilm formation and the electron transfer rate which agrees with Wilberforce et al. [44]. The vision of this research is to modify the electrode to strive for compatibility with bacteria for the improvement of the electrical energy generation which agree with the statements of Kaur et al. [45]. Liang et al. [46] have used graphene oxide and carbon nanotubes, where the present study used both materials too. However, the present study found that graphitic carbon nitride nanosheets outperformed both graphene oxide and carbon nanotubes. Also, the results showed high durability of the nanocoating electrodes $[47,48]$. Further studies have implemented different nanomaterials such as manganese oxide nanowires and nanorods [49] and nanocomposite of graphene and nickel nanoparticle [50] in a similar approach applied in the current study.

On the other hand, the bacteria are the main players in generating electrical energy within the microbial fuel cells such as Geobacter, Shewanella, and Pseudomonas [8] as well as Lysinibacillus strains, Chryseobacterium strains, Escherichia strains, and Bacillus strains [51], where future research should focus on the biostimulation of these MFC bacteria using nutrients in the form of nanomaterials as conducted in previous research on bacteria used in indifferent applications [52-59]. Other issues facing the implementation of MFCs in wastewater treatment plants are the material and cost of the anode electrode, where MFCs are still unfeasible for commercialization. Future research should focus on the use of natural and eco-friendly materials to build electrodes for microbial fuel cells [60-64].

\section{Conclusions}

According to the results of this study, it can be concluded that:

1. The coulombic efficiency of the microbial fuel cell where its electrodes are coated with graphitic carbon nitride nanosheets was higher than graphene, carbon nanotubes, and the control in a descending order, respectively.

2. Coating the electrodes with graphitic carbon nitride nanosheets increases the electrical conductivity of the microbial fuel cells which results in increasing the generated electrical power by 4.9 times the conventional method. 
3. Coating the electrodes with graphitic carbon nitride nanosheets increases the coulombic efficiency of the microbial fuel cells by 2.33 times the control.

4. Higher bacterial growth was recorded in the microbial fuel cells when the electrodes were coated nanomaterials compared to control.

5. Using a pump to intrude air (oxygen) into the cathode chamber has a strong positive effect on the amount of generated power from the microbial fuel cells.

6. Future research will focus on synthesizing novel nanomaterials to be used for coating the electrodes of microbial fuel cells in order to increase the electric energy generation from wastewaters.

Author contribution The manuscript was written through contributions of all the authors. All the authors have given approval to the final version of the manuscript.

Funding Open access funding provided by The Science, Technology \& Innovation Funding Authority (STDF) in cooperation with The Egyptian Knowledge Bank (EKB). This work was financially supported by Cairo University through the research project no. 143-2017.

Data availability All the data generated or analyzed during this study are included in this published article.

\section{Declarations}

Ethical approval This article does not contain any studies with human participants or animals performed by any of the authors.

Consent to participate Not applicable.

Consent for publication Not applicable.

Competing interests The authors declare no competing interests.

Open Access This article is licensed under a Creative Commons Attribution 4.0 International License, which permits use, sharing, adaptation, distribution and reproduction in any medium or format, as long as you give appropriate credit to the original author(s) and the source, provide a link to the Creative Commons licence, and indicate if changes were made. The images or other third party material in this article are included in the article's Creative Commons licence, unless indicated otherwise in a credit line to the material. If material is not included in the article's Creative Commons licence and your intended use is not permitted by statutory regulation or exceeds the permitted use, you will need to obtain permission directly from the copyright holder. To view a copy of this licence, visit http://creativecommons.org/licenses/by/4.0/.

\section{References}

1. Papaharalabos G, Greenman J, Melhuish C, Ieropoulos I (2015) A novel small scale microbial fuel cell design for increased electricity generation and waste water treatment. Int J Hydrogen Energy 40:4263-4268

2. Alzate-Gaviria L (2011) Microbial fuel cells for wastewater treatment in: waste water - treatment and reutilizationWaste water treatment and reutilization, F Einschlag (Ed), ISBN: 978-953307-249-4, InTech Europe, Rijeka. https://doi.org/10.5772/15546

3. Logan B (2008) Microbial fuel cells, 216 pp. John Wiley \& Sons Inc, Hoboken

4. Samer M (2015) Biological and chemical wastewater treatment processes In: Wastewater treatment engineering, M Samer (Ed), ISBN 978-953-51-4245-4, InTech Europe, Rijeka. https://doi. org/10.5772/61250

5. Karmakar S, Kundu K, Kundu S (2010) Design and development of microbial fuel cells Current. Res Technol Educ Top Appl Microbiol Microbial Biotechnol 2:1029-1034

6. An J, Sim J, Lee H-S (2015) Control of voltage reversal in serially stacked microbial fuel cells through manipulating current: significance of critical current density. J Power Sources 283:19-23

7. Madani S, Gheshlaghi R, Mahdavi MA, Sobhani M, Elkamel A (2015) Optimization of the performance of a double-chamber microbial fuel cell through factorial design of experiments and response surface methodology. Fuel 150:434-440

8. Luo J, Li M, Zhou M, Hu Y (2015) Characterization of a novel strain phylogenetically related to Kocuria rhizophila and its chemical modification to improve performance of microbial fuel cells. Biosens Bioelectron 69:113-120

9. Prasath SS, Arockiarajan A (2015) Effect of interphase and thermal environment on the effective properties of macro-fiber composites (MFC). Compos B 75:327-335

10. Wu S, Liang P, Zhang C, Li H, Zuo K, Huang X (2015) Enhanced performance of microbial fuel cell at low substrate concentrations by adsorptive anode. Electrochim Acta 161:245-251

11. Zhang C, Liang P, Jiang Y, Huang X (2015) Enhanced power generation of microbial fuel cell using manganese dioxide-coated anode in flow-through mode. J Power Sources 273:580-583

12. Baranitharan E, Khan MR, Prasad D, Teo W, Tan G, Jose R (2015) Effect of biofilm formation on the performance of microbial fuel cell for the treatment of palm oil mill effluent. Bioprocess Biosyst Eng 38:15-24

13. Vilajeliu-Pons A, Puig S, Pous N, Salcedo-Dávila I, Baneras L, Balaguer MD, Colprim J (2015) Microbiome characterization of MFCs used for the treatment of swine manure. J Hazard Mater 288:60-68

14. Mohamed YMA, Attia YA, El Nazer HA, Solum EJ (2021) An overview of recent development in visible light-mediated organic synthesis over heterogeneous photo-nanocatalysts. Curr Org Synth 18(1):23-36

15. Abdelsalam EM, Mohamed YMA, Abdelkhalik S, El Nazer HA, Attia YA (2020) Photocatalytic oxidation of nitrogen oxides (NOx) using Ag- and Pt-doped $\mathrm{TiO}_{2}$ nanoparticles under visible light irradiation. Environ Sci Pollut Res 27:35828-35836

16. Guo R, Ni L, Zhang H, Gao X, Momen R, Massoudi A, Zou G, Hou H, Ji X (2021) $\mathrm{MnO}_{2}$ Nanowires anchored with graphene quantum dots for stable aqueous zinc-ion batteries. ACS Appl Energy Mater 4(10):10940-10947

17. Attia YA, Abdel-Hafez Sh (2021) Nano $\mathrm{Co}_{3} \mathrm{O}_{4}$ catalyzed microwave-assisted one-pot synthesis of some seleno[2,3-b] pyridine/ quinoline derivatives. Res Chem Intermed 47(9):3719-3732

18. Janicek A, Fan Y, Liu H (2015) Performance and stability of different cathode base materials for use in microbial fuel cells. J Power Sources 280:159-165

19. Rabaey K, Verstraete W (2005) Microbial fuel cells: novel biotechnology for energy generation. Trends Biotechnol 23(6):291-298

20. Chen D, Zhou M, Hu J, Kang Z (2021) Adhesive, reflective, and conductive films comprised of graphene nanosheets decorated 
with Ag nanoparticles for flexible electronics. Appl Surface Sci 543:148802

21. Dhineshbabu NR, Mahadevi N, Assein D (2020) Electronic applications of multi-walled carbon nanotubes in polymers: a short review. Mater Today Proc 33(1):382-386

22. Idris AO, Oseghe EO, Msagati TAM, Kuvarega AT, Feleni U, Mamba B (2020) Graphitic carbon nitride: a highly electroactive nanomaterial for environmental and clinical sensing. Sensors 20:5743

23. Altalhi T, Mezni A, Aldalbahi A, Alrooqi A, Attia Y, Santos A, Losic D (2016) Fabrication and characterization of sulfur and phosphorus (S/P) co-doped carbon nanotubes. Chem Phys Lett 658:92-96

24. Attia YA, Al Nazawi AM, Elsayed H, Sadik MW (2021) Carbon nanotubes catalyzed UV-trigger production of hyaluronic acid from Streptococcus equi. Saudi J Biol Sci 28(1):484-491

25. Hummers WS, Offeman RE (1958) Preparation of graphitic oxide. J Am Chem Soc 80:1339-1339

26. Alam SN, Sharma N, Kumar L (2017) Synthesis of graphene oxide (GO) by Modified hummers method and its thermal reduction to obtain reduced graphene oxide (rGO). Graphene 6:1-18

27. Attia YA (2016) Ag/ZnO/graphene-TBSCl hybrid nanocomposite as highly efficient catalyst for hydrogen production. Mater Express 6(3):211-219

28. Attia YA, Mohamed YMA, Altalhi TA (2016) Photobiosynthesis of metal/graphene nanocomposites: new materials for water desalination and purification. Desalin Water Treat 57(54):26014-26021

29. Attia YA, Mohamed YMA (2019) Silicon-grafted Ag/AgX/rGO nanomaterials ( $\mathrm{X}=\mathrm{Cl}$ or $\mathrm{Br}$ ) as Dip-photocatalysts for highly efficient p-nitrophenol reduction and paracetamol production. Appl Organometallic Chem 33:e4757

30. Attia YA, Vázquez-Vázquez C, Mohamed YMA (2017) Facile production of vitamin B3 and other heterocyclic carboxylic acids using an efficient $\mathrm{Ag} / \mathrm{ZnO} /$ graphene-Si hybrid nanocatalyst. Res Chem Intermed 43(1):203-218

31. Attia YA, Attia SY, Essa R, Mohamed S (2020) Photosynthesis of chromium oxide/reduced graphene oxide nanocomposites and its application in water desalination and purification. Nanosci Nanotechnol Asia 10(5):719-725

32. Kanwal A, Yaqoob AA, Siddique A, Bhawani SA, Ibrahim MNM, Umar K (2021) Hybrid nanocomposites based on graphene and its derivatives: from preparation to applications. In: Qaiss AK, Bouhfid R, Jawaid M (eds) Graphene and nanoparticles hybrid nanocomposites 261-281. Composites Science and Technology. Springer, Singapore. https://doi.org/10.1007/978-981-33-4988-9_ 10

33. Verma S, Varma RS (2017) Photocatalytic oxidation of aromatic amines using $\mathrm{MnO}_{2} @ \mathrm{~g}-\mathrm{C}_{3} \mathrm{~N}_{4}$. Adv Mater Lett 8(7):754-756

34. Attia YA, Samer M, Moselhy MA, Arisha AH, Abdelqader AA, Abdelsalam EM (2021) Influence of laser photoactivated graphitic carbon nitride nanosheets and nickel nanoparticles on purple nonsulfur bacteria for biohydrogen production from biomass. J Clean Prod 299(3): 126898

35. Seghiouer A, Chevalet J, Barhoun A, Lantelme F (1998) Electrochemical oxidation of nickel in alkaline solutions: a voltammetric study and modelling. J Electroanal Chem 442(1-2):113-123

36. Liu H, Cheng S, Logan B (2005) Production of electricity from acetate and butyrate in a single chamber microbial fuel cell. Environ Sci Technol 39:658-662

37. Tao Q, Zhou S, Luo J, Yuan J (2015) Nutrient removal and electricity production from wastewater using microbial fuel cell technique. Desalination 365:92-98

38. Yue X, Yi S, Wang R, Zhang Z, Qiu S (2016) Cadmium sulfide and nickel synergetic co-catalysts supported on graphitic carbon nitride for visible-light-driven photocatalytic hydrogen evolution. Sci Rep 6:22268
39. Soomro SA, Gul IH, Naseer H, Marwat S, Mujahid M (2019) Improved performance of $\mathrm{CuFe} 2 \mathrm{O} 4 / \mathrm{rGO}$ nanohybrid as an anode material for lithium-ion batteries prepared via facile one-step method. Curr Nanosci 15:420-429

40. Chen X, Cui D, Wang X, Wang X, Li W (2015) Porous carbon with defined pore size as anode of microbial fuel cell. Biosens Bioelectron 69:135-141

41. Cui H-F, Du L, Guo P-B, Zhu B, Luong J (2015) Controlled modification of carbon nanotubes and polyaniline on macroporous graphite felt for high-performance microbial fuel cell anode. J Power Sources 283:46-53

42. Erbay C, Pu X, Choi W, Choi M-J, Ryu Y, Hou H, Lin F, de Figueiredo P, Yu C, Han A (2015) Control of geometrical properties of carbon nanotube electrodes towards high-performance microbial fuel cells. J Power Sources 280:347-354

43. Kamali M, Aminabhavi TM, Abbassi R, Dewil R, Appels L (2022) Engineered nanomaterials in microbial fuel cells - recent developments, sustainability aspects, and future outlook. Fuel 310(Part B): 122347

44. Wilberforce T, Abdelkareem MA, Elsaid K, Olabi AG, Sayed ET (2022) Role of carbon-based nanomaterials in improving the performance of microbial fuel cells. Energy 122478

45. Kaur R, Marwaha A, Chhabra VA, Kim K-H, Tripathi SK (2020) Recent developments on functional nanomaterial-based electrodes for microbial fuel cells. Renew Sustain Energy Rev 119:109551

46. Liang Y, Zhai H, Liu B, Ji M, Li J (2020) Carbon nanomaterialmodified graphite felt as an anode enhanced the power production and polycyclic aromatic hydrocarbon removal in sediment microbial fuel cells. Sci Total Environ 713:136483

47. Yaqoob AA, Ibrahim MNM, Umar K (2021) Biomass-derived composite anode electrode: synthesis, characterizations, and application in microbial fuel cells (MFCs). J Environ Chem Eng 9(5): 106111

48. Yaqoob AA, Ibrahim MNM, Yaakop AS, Umar K, Ahmad A (2021) Modified graphene oxide anode: a bioinspired waste material for bioremediation of $\mathrm{Pb}^{2+}$ with energy generation through microbial fuel cells. Chem Eng J 417:128052

49. Farahani FS, D'Epifanio A, Majidi MR, Placidi E, Arciprete F, Mecheri B (2020) Tailoring morphology and structure of manganese oxide nanomaterials to enhance oxygen reduction in microbial fuel cells. Synth Met 268:116487

50. Valipour A, Ayyaru S, Ahn Y (2016) Application of graphenebased nanomaterials as novel cathode catalysts for improving power generation in single chamber microbial fuel cells. J Power Sources 327:548-556

51. Daud NNM, Ahmad A, Yaqoob AA, Ibrahim MNM (2021) Application of rotten rice as a substrate for bacterial species to generate energy and the removal of toxic metals from wastewater through microbial fuel cells. Environ Sci Pollut Res 28(44):62816-62827

52. Samer M, Hijazi O, Abdelsalam EM, El-Hussein A, Attia YA, Yacoub IH, Bernhardt H (2021) Life cycle assessment of using laser treatment and nanomaterials to produce biogas through anaerobic digestion of slurry. Environ Dev Sustain. https://doi. org/10.1007/s10668-021-01264-9

53. Abdelsalam EM, El-Hussein A, Samer M (2021) Photobiostimulation of anaerobic digestion by laser irradiation and photocatalytic effects of trace metals and nanomaterials on biogas production. Int J Energy Res 45:141-150

54. Samer M, Abdelsalam EM, Mohamed S, Elsayed H, Attia YA (2021) Impact of photoactivated cobalt oxide nanoparticles addition on manure and whey for biogas production through dry anaerobic co-digestion. Environ Dev Sustain. https://doi.org/10.1007/ s10668-021-01757-7

55. Hijazi O, Abdelsalam E, Samer M, Attia YA, Amer BMA, Amer MA, Badr M, Bernhardt H (2020) Life cycle assessment of the use 
of nanomaterials in biogas production from anaerobic digestion of manure. Renew Energy 148:417-424

56. Hijazi O, Abdelsalam E, Samer M, Amer BMA, Yacoub IH, Moselhy MA, Attia YA, Bernhardt H (2020) Environmental impacts concerning the addition of trace metals in the process of biogas production from anaerobic digestion of slurry. J Clean Prod 243:118593

57. Abdelsalam EM, Samer M (2019) Biostimulation of anaerobic digestion using nanomaterials for increasing biogas production. Rev Environ Sci Bio/Technology 18(3):525-541

58. Abdelsalam E, Samer M, Attia Y, Abdel-Hadi MA, Hassan HE, Badr Y (2019) Effects of laser irradiation and Ni nanoparticles on biogas production from anaerobic digestion of slurry. Waste Biomass Valoriz 10(11):3251-3262

59. Attia YA, Kobeasy MI, Samer M (2018) Evaluation of magnetic nanoparticles influence on hyaluronic acid production from Streptococcus equi. Carbohydr Polym 192:135-142

60. Yaqoob AA, Ibrahim M, Umar K, Parveen T, Ahmad A, Lokhat D, Mohd-Setapar S (2021) A glimpse into the microbial fuel cells for wastewater treatment with energy generation. Desalin Water Treat 214:379-389

61. Yaqoob AA, Khatoon A, Mohd Setapar SH, Umar K, Parveen T, Mohamad Ibrahim MN, Ahmad A, Rafatullah M (2020) Outlook on the role of microbial fuel cells in remediation of environmental pollutants with electricity generation. Catalysts 10(8):819

62. Yaqoob AA, Ibrahim MNM, Guerrero-Barajas C (2021) Modern trend of anodes in microbial fuel cells (MFCs): an overview. Environ Technol Innov 23:101579

63. Yaqoob AA, Ibrahim MNM, Rafatullah M, Chua YS, Ahmad A, Umar K (2020) Recent advances in anodes for microbial fuel cells: an overview. Materials 13(9):2078

64. Yaqoob AA, Ibrahim MNM, Rodríguez-Couto S (2020) Development and modification of materials to build cost-effective anodes for microbial fuel cells (MFCs): an overview. Biochem Eng J 164:107779

Publisher's note Springer Nature remains neutral with regard to jurisdictional claims in published maps and institutional affiliations. 